\title{
BioéthiqueOnline
}

\section{Beyond Doing Good: An Interview with Dr. Kirsten Johnson on the Canadian Disaster and Humanitarian Response Training Program}

\author{
Élysée Nouvet
}

Volume 4, 2015

Reçu : 15 May 2015; publié : 8 Oct 2015; éditrices : Lise Lévesque \& Mariana Nunez

URI : https://id.erudit.org/iderudit/1035511ar

DOI : https://doi.org/10.7202/1035511ar

Aller au sommaire du numéro

Éditeur(s)

BioéthiqueOnline

ISSN

1923-2799 (numérique)

Découvrir la revue

Citer ce compte rendu

Nouvet, É. (2015). Compte rendu de [Beyond Doing Good: An Interview with Dr. Kirsten Johnson on the Canadian Disaster and Humanitarian Response Training Program]. BioéthiqueOnline, 4. https://doi.org/10.7202/1035511ar
Résumé de l'article

Ce texte présente la synthèse d'une entrevue avec Dr Kirsten Johnson, un médecin canadien pleinement engagé dans la formation des médecins à l'intervention humanitaire. Dr Johnson démontre que la formation basée sur la simulation est essentielle au développement des compétences humanitaires de base ainsi qu'au façonnement de l'attitude éthique. Elle insiste sur le devoir du Canada d'assurer la formation appropriée de ses professionnels de la santé avant de les envoyer en mission humanitaire. 


\title{
Beyond Doing Good: An Interview with Dr. Kirsten Johnson on the Canadian Disaster and Humanitarian Response Training Program
}

\author{
COMPTE RENDU / REVIEW \\ Élysée Nouvet ${ }^{1}$ \\ Reçu/Received: 15 May 2015 \\ Publié/Published: 8 Oct 2015 \\ Éditrices/Editors: Lise Lévesque \& Mariana Nunez \\ 2015 É Nouvet, Creative Commons Attribution 4.0 International License
}

\section{Résumé}

Ce texte présente la synthèse d'une entrevue avec Dr Kirsten Johnson, un médecin canadien pleinement engagé dans la formation des médecins à l'intervention humanitaire. Dr Johnson démontre que la formation basée sur la simulation est essentielle au développement des compétences humanitaires de base ainsi qu'au façonnement de l'attitude éthique. Elle insiste sur le devoir du Canada d'assurer la formation appropriée de ses professionnels de la santé avant de les envoyer en mission humanitaire.

\section{Mots clés}

réponse humanitaire, éducation médicale, formation basée sur la simulation, compétences humanitaires de base, éthique

\section{Summary}

This text presents a synthesis of an interview with Dr. Kirsten Johnson, a Canadian physician fully engaged in training health professionals in humanitarian response and intervention. Dr. Johnson shows that simulation-based training is essential to the development of core humanitarian competencies and to the shaping of ethical attitudes as well. She stresses Canada's duty to assure appropriate training of its health professionals before sending them out on humanitarian missions.

\section{Keywords}

humanitarian response, medical education, simulationbased training, core humanitarian competencies, ethics

Affiliations des auteurs / Author Affiliations

${ }^{1}$ Clinical Epidemiology and Biostatistics, McMaster University, Hamilton Ontario, Canada

\section{Correspondance / Correspondence}

Élysée Nouvet, nouvete@gmail.com

\section{Remerciements}

Remerciements spéciaux à Dr. Johnson pour l'entrevue, aux éditrices de BioéthiqueOnline, Lise Lévesque et Mariana Nunez pour leur rétroaction utile et détaillée sur le texte et au Groupe de recherche en éthique des soins humanitaires pour leur appui constant.

\section{Conflit d'intérêts}

Aucun déclaré

\section{Acknowledgements}

Special thanks to Dr. Johnson for this interview, to the BioéthiqueOnline editors Lise Lévesque \& Mariana Nunez for their detailed and helpful feedback on this piece, and to the Humanitarian Healthcare Ethics Research Group for their ongoing support.

\section{Conflicts of Interest}

None declared

\section{Preamble}

Saving lives lies at the core of humanitarianism's ethical legitimacy. Promises and ability of specific humanitarian responses to rescue and/or protect life invariably colour evaluations of these as moral or not $[1,2]$. As many have noted over the last decade, however, the ethical performance of humanitarian responses cannot be reduced to biological measurables. 'Doing good' depends not only on what is delivered, to whom, and how fast, but also on how humanitarian assistance is provided and perceived $[3,4]$. As such, 'doing good' depends on skilled communications and coordination, good data collection and analysis, aid workers' respectful engagements in unfamiliar contexts, and, not least of all, the ability of organizations and individuals to mitigate potential psychological, professional, organizational, and political damage in unexpected and high-stress scenarios. 
Recognizing the multi-layered, inter-personal and contextual contingencies of "doing good" is one thing, but integrating such understanding into ethical practice is another. One Canadian global health scholar and emergency room doctor is determined to do just this. With her headquarters in Montreal, Dr. Kirsten Johnson is the founder and director of the Canadian Disaster and Humanitarian Response Training Program. In this interview, conducted in May 2015, Dr. Johnson explains how this simulationbased training strives to shrink the gap between humanitarian professionals' intention and ability to enact ethically-sound practice, and why doing so is crucial at this juncture.

\section{Interview}

Nouvet: Why start this training program in Canada?

Johnson: There can still be an assumption that if we go [join a humanitarian response], we'll do good. We can't be so Pollyanna about that anymore. When we go to these countries, we are with professionals. They are trained. We are there just to support them. The thing is: how do you do that? There is such a gap between what is written on a piece of paper and what a situation is actually like. When I did my MPH at Harvard, it was a lot of that: the stuff on paper. I have realized that you have to marry the two together: the stuff on paper and practice. That's the point of this program.

Nouvet: Your Program includes sessions by experts on a vast range of topics. It also features what you call a "Simulation Exercise": participants are immersed during 72 hours in a setting "designed to simulate a complex humanitarian emergency that involves understanding cultural context, war, natural disaster and forced migration of the local population in addition to other challenges injected to add stress to the participants." What importance does the simulation play in participants' education?

Johnson: Compare it to an operating theatre. As a physician, you go to medical school and you learn the theory and you have to pass tests so you're competent on some level. But it's not until you get into the operating theatre when you actually have to practice, and you're scrubbing in and you're holding the scalpel and working as part of that team and talking the same language and collaborating that you really understand. And so, if you're talking about training humanitarian professionals that are going to go encounter these scenarios, you need to do this. The prime goal of doing simulation is to give people the chance to put themselves in a realistic scenario and stress the hell out of them, so that they experience what it's going to be like in the field. And sometimes people say, "I don't want to do this. It's not what I thought it would be for me." And that's great, because you know what? Let's have them drop out here, before they go to the field and they're stuck in the middle of nowhere, in a situation that's very difficult for them. We are very sensitive to the fact that we trigger people. Some people have been refugees, they have PTSD [post-traumatic stress disorder] because they've been through conflict, so it's allowing them to experience how they're going to react but in a supportive environment. We have trained professionals there to help them. That's the main aim of the simulation.

The simulation also allows us also to test competencies. There's a globally recognized competency framework now that everyone is trying to teach but there are a lot of soft skills that you cannot teach in a classroom. How do you roll an effective team? How do you make sure you're effective in a team? How do you cope with stress? All of these things, we evaluate them on, and we give them feedback in real time.

Nouvet: Why 3 days? 
Johnson: We found that if you just do a day, people know that at the end of the day they can go home and have a shower and have a hot meal. By the end of two full days, and if the weather is bad, people are beat. It just drains you. It's exhausting. We have so many teams and you have to roll them through coordinated skill stations and activities and they're being evaluated on each. You need time for that but it also gives time to participants to get a grip on what they need to do. With three days, it allows us to ramp things up. One of the nights we always do a militia attack which is quite scary. Sunday morning they present their deliverables. What creates stress for them is not just that we're popping child soldiers into the game and playing with militia. They have to get work done. They have to do media interviews. They have to attend UN meetings, follow security commands, radio in. They've got to practice evacuating. If they are in the Médecins Sans Frontières NGO team, they might need to organize a vaccination campaign. That means they have to determine what's the vaccination rate for adults? For under 5 s? How are they going to manage the cold chain? And all the while they're being interrupted and they have to do all the skill stations and create situation reports.

Nouvet: I have heard from colleagues that some participants in the past were overwhelmed and did break down. Have you adjusted the curriculum to decrease the stress on participants over the years?

Johnson: Yes. One year, we outsourced to someone and he was doing stuff like [simulating] killing the participants. That was really too much. It wasn't learning: it was upsetting. People were crying and stuff. The stations now are run by our guys, and we really do a lot of debriefing with participants. Trainers are sensitive to the students as they're going through and they break out of role when necessary. It's a supportive situation. Because it can be quite scary, you know, if you're driving in a convoy and your vehicle gets ambushed by these big guys running at you, all covered in bandanas and with guns and they make you get out of the car and kneel down. There's a lot of discussion about having the night-time raid because last year we really scared participants. Really scared them. However, it's also important. Because I was just talking to someone who opened up the course today as the lead lecturer, and he said that he's back because he was held up with a Kalashnikov in the field and he's got PTSD and he's having a hard time. Another guy who took our course, he's also on stress leave from the UN [United Nations] with PTSD. So, this is a controlled setting: we've got the support people, really good people. How else are you going to get that experience? How else can you know what it's like and know how you're going to manage yourself if you don't do some of that?

Nouvet: Do you see this kind of training as reflecting or contributing to an ethical shift in Canadian humanitarian practice?

Johnson: In Canada, we've really set a precedent with this Canadian initiative in that we've created a national community that has come together and said "We will not accept less than professional and competently trained humanitarians representing Canada in these situations." There's a new law called International Disaster Response Law that is under the mandate of the ICRC [International Committee of the Red Cross] that outlines that countries also have a right, sovereign nations have a right to know "Who are these people coming in? What kind of training do they have?" And more countries are putting up these barriers and saying, "We don't want you if you haven't got this [training]."

Last year, colleagues and I were working with the Canadian Medical Association to write a white paper aimed at introducing a policy that would mandate that all physicians should have this training before assisting in a humanitarian crisis. All. It's not because you are a doctor that you know how to do this. We saw doctors in Haiti cutting off people's legs after 
the earthquake in 2010 with no anesthetic, no field hospital, no adjunct surgeon. Volunteers urinating on tents and supplies because they weren't paying attention to where they should be going to the bathroom. Placing post-it notes with antibiotics we use here in North America - because we have them here but they don't there - onto patients' foreheads after they'd amputated their legs just assuming that some nurse was going to come and start the IV and given them these meds. People were dying from these field amputations. Volunteers didn't understand how to triage. There was no coordination or collaboration on the ground. It impeded humanitarian effort by these organizations who knew what they were doing. You can do more harm than good.

Nouvet: Final thoughts?

Johnson: If we're putting resources towards humanitarian assistance, tax payers' dollars, we need to make sure that these people are trained. And not only in terms of the services they are providing and what they are delivering, but also for their own safety and security. Otherwise you have Canadians getting kidnapped and all the rest. We don't want people coming back like Romeo D'Allaire, with PTSD, or suicide attempts, or alcoholism. And that is the trend at the moment. We have an obligation to make sure these people are better prepared.

\section{Biography}

Elysée Nouvet (PhD) is a research fellow in Humanitarian Healthcare Ethics at McMaster University in Hamilton, Ontario, with an interest in social dimensions of suffering, cultures of care, and ethics education.

\section{List of References}

1. Fassin D. Humanitarianism as a Politics of Life. Public Culture. 2007; 19(3): 499-520.

2. Redfield P. The Unbearable Lightness of Expats: Double Binds of Humanitarian Mobility. Cultural Anthropology. 2012; 27(2): 358-382.

3. Oudar M. Jeux de miroir. Réflexions sur MSF et l'action humanitaire. Humanitaire, 2014; 37:112-113.

4. Slim H. By What Authority? The Legitimacy and Accountability of Non-governmental Organisations. International Meeting on Global Trends and Human Rights - Before and after September 11. The International Council on Human Rights Policy. Geneva, Switzerland. 2002. 